\title{
Observations of neutral winds in the polar cap during northward IMF
}

\author{
R. J. NiciejeWski, T. L. Killeen and Y. WoN \\ Space Physics Research Laboratory, University of Michigan, Ann Arbor, Michigan, U.S.A.
}

(Received in final form 9 February 1993; accepted 9 February 1993)

\begin{abstract}
Long term remote observations of neutral winds at $F$-region altitudes have been performed at Thule Air Base (lat. $76.5 \mathrm{~N}$, long. $69.0^{\circ} \mathrm{W}$ ), Greenland, and Søndre Strømfjord (lat. $67.0^{\circ} \mathrm{N}$, long. $50.9^{\circ} \mathrm{W}$ ), Greenland. The former site is very close to the geomagnetic pole, while the latter site is within the polar cap for several hours each night on either side of geomagnetic midnight. Wind data corresponding to clear sky conditions and $K p \leqslant 4$ were sorted according to the sign of the IMF $B_{z}$ component. The averaged maximum poleward flow near midnight LST was reduced by approximately one third during $B_{\text {z }}$ northward conditions. If the magnitude of $B_{1}$ was less than the magnitude of the northward $B_{z}$ component, then the averaged poleward flow was further reduced by one half. In addition, if $B_{s}>5 \mathrm{nT}$, then sunward directed horizontal neutral winds were observed at the very highest latitudes near noon LST.
\end{abstract}

\section{INTRODUCTION}

Initial models of the horizontal neutral wind flow in the thermosphere above the polar cap indicated that the wind flowed across the polar regions away from the midafternoon pressure bulge (KoHL and KING, 1967). These calculations did not take into account any high latitude heating due to charged particle precipitation resulting in horizontal winds that always displayed an anti-sunward component. Observations of the polar horizontal neutral wind field by the Dynamics Explorer 2 (DE-2) satellite provided new insight regarding the effects of auroral processes on the neutral wind flow (KILlEEN et al., 1982). These data sets clearly indicated the presence of a two component wind field superimposed upon the predicted flow associated with the pressure bulge. A strong antisunward flow over the polar cap was observed with return flows both in the evening and in the morning sectors. The two cells thus formed describe a clock wise rotation in the dusk sector when viewed from above, and a counter clockwise rotation in the dawn sector.

The twin cell structure is similar to the empirically derived convection patterns of HEPPNER (1977) and HEPPNER and MAYNARD (1987) for the high latitude electric field. Here, the electric field models are shown with a dependency based on the interplanetary magnetic field (IMF) $B_{3}$ and $B_{z}$ components. The horizontal motion of the neutral atoms and molecules in the polar thermosphere, particularly during solar maximum conditions, is controlled to some degree by the motion of the ions which are required to follow the direction of the electric field. At high latitudes, some of the momentum of the plasma drift is transferred to the neutral constituents through the ion drag force with a time constant representative of the ion densities (PONTHEU et al., 1988), and with values ranging from less than an hour for daytime solar maximum to about $20 \mathrm{~h}$ for nighttime solar minimum periods. Several studies have appeared which describe the influence of the $B_{r}$ component on the horizontal neutral wind at high latitudes. MCCORMAC and SMirH (1984) describe ion drift and neutral wind results from a station in Spitsbergen. They indicate a definite influence on the zonal neutral wind based upon the sign of the IMF $B_{1}$ component. MCCORMAC et al. (1985) describe a similar dependence of the neutral circulation pattern for IMF $B_{y}$ conditions based upon several key DE-2 orbits. In a more detailed study of the DE-2 data, THAyer et al. (1987) show that, at high latitudes in the northern hemisphere, the dusk cell formed by the neutral circulation pattern encroaches upon the dawn cell for $B_{y}$ positive conditions, while the two cells are more similar in size when $B_{\text {, }}$ is negative. In both cases, the binning of data was only performed for data where the $B_{z}$ component was either southward or less than $+1 \mathrm{nT}$. REES ef al. (1986) have also discussed this asymmetry using DE2 and ground-based measurements from Kiruna. Additional studies describing IMF $B_{v}$, dependences on the high latitude horizontal neutral wind are given by MERIWETHER and SHIH (1987), SiCA et al. (1989), and NiCIEJEWSKI et al (1992) for the northern hemisphere, and by HernANDEZ et al. (1991) for the southern hemisphere.

Studies involving the effect of the northward/ southward, or the $+1-B_{-}$, component of the IMF on the neutral circulation pattern have not been as numerous. Ion drift medsurements described by 
Heelis et al. (1986) point to a more complex ionospheric convection paltern when $B_{z}$ is northward. The observed convection velocities are usually smaller when the IMF is northward with sunward flow occurring at the highest latitudes. Their data suggest that a four cell convection pattern exists for $B_{z}$ northward, with a dependence on the sign of $B_{3, w}$ with the two highest latitude cells circulating opposite to that seen for $B_{z}$ southward conditions. Alternatively, their data could be interpreted in terms of a 'distorted' two cell pattern promoted by HEPPNER and MAYNARD (1987) for northward $B_{z}$. KILLEEN et al. (1985) present neutral wind measurements for a period in which the sign of $B_{-}$was northward for $11 \mathrm{~h}$. Both ion drifts and neutral winds within the central polar cap region pointed sunward, with the horizontal neutral wind magnitude about $10 \%$ of the ion drift magnitude. The fact that the neutral wind flowed sunward is indicative of a strong sunward ion drag force, since the strong pressure gradient force is always directed anti-sunward. In a more detailed study of the DE-2 neutral wind data base, MCCormac et al. (1991) discussed the IMF $B$ - dependence of the thermospheric horizontal neutral wind circulation pattern at high latitudes. The study concentrated on data acquired during winter solstice at solar maximum conditions. They concluded that, during periods when $B_{\text {. }}$ was northward, sunward horizontal neutral winds developed in the thermosphere at high latitudes in the northern hemisphere. The occurrence of sunward winds also depended on the magnitude of $B_{y}$ in relation to the magnitude of $B_{z}$.

In this paper, observations of the horizontal neutral wind in the polar regions at thermospheric heights are ordered according to the sign of IMF $B$ : and the magnitude of IMF $B_{1}$. The condensed data sets provide additional evidence relating to the effect of the IMF on the circulation of the neutral winds within the polar cap.

\section{DATA ANALySIS}

The University of Michigan maintains and operates two Fabry-Perot interferometers in Greenland: one at Thule Air Base (lat. $76.5^{\circ} \mathrm{N}$, long. $69^{\circ} \mathrm{W}$ ), and the other at Søndre Strømfjord (lat. $67^{\circ} \mathrm{N}$, long. $50.9^{\circ} \mathrm{W}$ ). The instruments and the method by which the stations are operated are similar to that described by Meriwether et al. (1983). The interferometers were run in an unmanned, automatic patrol mode with a five position pointing scheme acquiring data from geographic north, east, west, and south azimuthal directions at $45^{\circ}$ zenith angle followed by an acquisition in the vertical direction. A neon lamp instrumental drift check followed by a dark count scan completed the sequence. A complete sequence was required between 15 and $60 \mathrm{~min}$ for completion depending on airglow emission intensities and whether the system acquired data with more than one filter. For this study, the filter bandwidths were measured to be $3 \AA$ at the FWHM positions, centered at $6300 \AA$. The data sets chosen for this study corresponded to the periods September 1987-January 1988 and November 1988March 1989 for Thule Air Base and September 1987 April 1988 and September 1988-April 1989 for Søndre Strømfjord. Both sites are near meteorological stations which provided information regarding overhead cloud cover conditions at $1 \mathrm{~h}$ intervals during the observation periods.

The raw data sets were reduced to geophysical parameters using reduction routines described by $\mathrm{K}_{\mathrm{II}}$ LEEN and HAYS (1984). Instrumental profiles were acquired with the use of a frequency stabilized HeNe laser. The data sets were then filtered according to $K p$ values and cloud cover conditions. Winds acquired when $K p \leqslant 4$ and cloud cover $\leqslant 3 / 8$ were then further processed according to the sign and stability of $B_{*}$, that is, the sign of $B_{z}$ must have been constant for at least $2 \mathrm{~h}$. This latter requirement helps assure that the horizontal neutral wind in the thermosphere has had some time to react to a change in the sign of $B_{i}$. The data sets were also subdivided into two groups depending on the ratio of the $B_{y}$ component to the $B_{\text {z component. Final averaged neutral wind values }}$ reported here are shown as $1 \mathrm{~h}$ binned averages with $\pm 1 \sigma$ standard deviations overlain. Averaged interplanetary magnetic field values were supplied by the NSSDCA data base in GSM coordinates at both $1 \mathrm{~h}$ and $15.36 \mathrm{~s}$ temporal resolution.

\section{RESULTS AND DISCUSSION}

\section{Case study, days 350-355, 1988}

This period coincides to an interval in which the IMP 8 satellite was in the solar wind. Figure 1 shows the IMF conditions during this period at the highest available temporal resolution (15.36 s). The IMF $B_{1}$ and $B_{z}$ components are shown in GSM coordinates. Certain regions are blank corresponding to data gaps in the record. This period was characterized by low to moderate geomagnetic activity, with $K p$ values ranging between 1 and 6 , with the most active period occurring late on day 352 and early on day 353 . In addition, the sign of $B_{z}$ was northward for extensive periods permitting a chance to easily view the effect of northward IMF on the neutral horizontal winds at 
high latitudes. Time periods in which the sign of $B_{z}$ was northward for several hours occurred between 07 and 14 UT on day 350 (case 1), 12 and 18 UT on day 352 (case 2), 03 and 11 UT on day 353 (case 3), and 07 and 15 UT on day 355 (case 4). In all these cases, the magnitude of the $B_{\text {z }}$ component was approximately $5 \mathrm{nT}$. There was also one interesting case in which $B$. was northward, but very close to zero; in fact

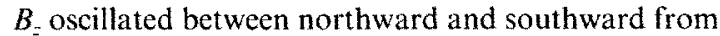
12 to 18 UT on day 353 .

Figure 2 displays meridional and zonal horizontal wind components above Thule Air Base during this period. The sign convention chosen places positive meridional wind as northward and positive zonal wind as eastward. The viewing conditions at Thule were excellent during this interval, with only the last few hours of day 355 contaminated by clouds. It is clear that there is variability in the wind, but this variation overlays a background diurnal component with the meridional and the zonal components $6 \mathrm{~h}$ out of phase. A typical diurnal cycle for $B_{z}$ southward conditions exists for day 351 . Here, the maximum poleward wind occurs near 16 UT (local noon) with a magnitude of $600 \mathrm{~m} / \mathrm{s}$. The zonal wind reaches its greatest value about $6 \mathrm{~h}$ later, also with a magnitude near $600 \mathrm{~m} / \mathrm{s}$.

Close examination of the four long term $B_{z}$ northward cases described above provides an indication of the effect of $B_{z}>0$ on the high latitude thermosphere. During case (1), the horizontal wind is primarily zonal in direction with a peak magnitude occurring at the same time as on day 351 , during the $B_{\text {: }}$ southward case. However, the absolute magnitude of the horizontal wind is decreased to only $250 \mathrm{~m} / \mathrm{s}$. The variation during case (2) is much more complicated. The sign of the IMF $B_{z}$ component is northward at the beginning of day 352 , but reaches $0 \mathrm{nT}$ at 01 UT, becomes northward for a few hours, and then becomes sharply southward for a long period at $\sim 0615$ UT. The neutral wind appears to follow the expected variations in both components though the zonal wind approaches zero earlier than on the previous day. Later on during day 352 , the IMF $B_{-}$component becomes northward for an extensive period beginning at 12 UT. This is the time at which the meridional neutral wind component begins to turn equatorward, rather than continuing to peak in the poleward direction. Unfortunately, the IMF data are missing beyond
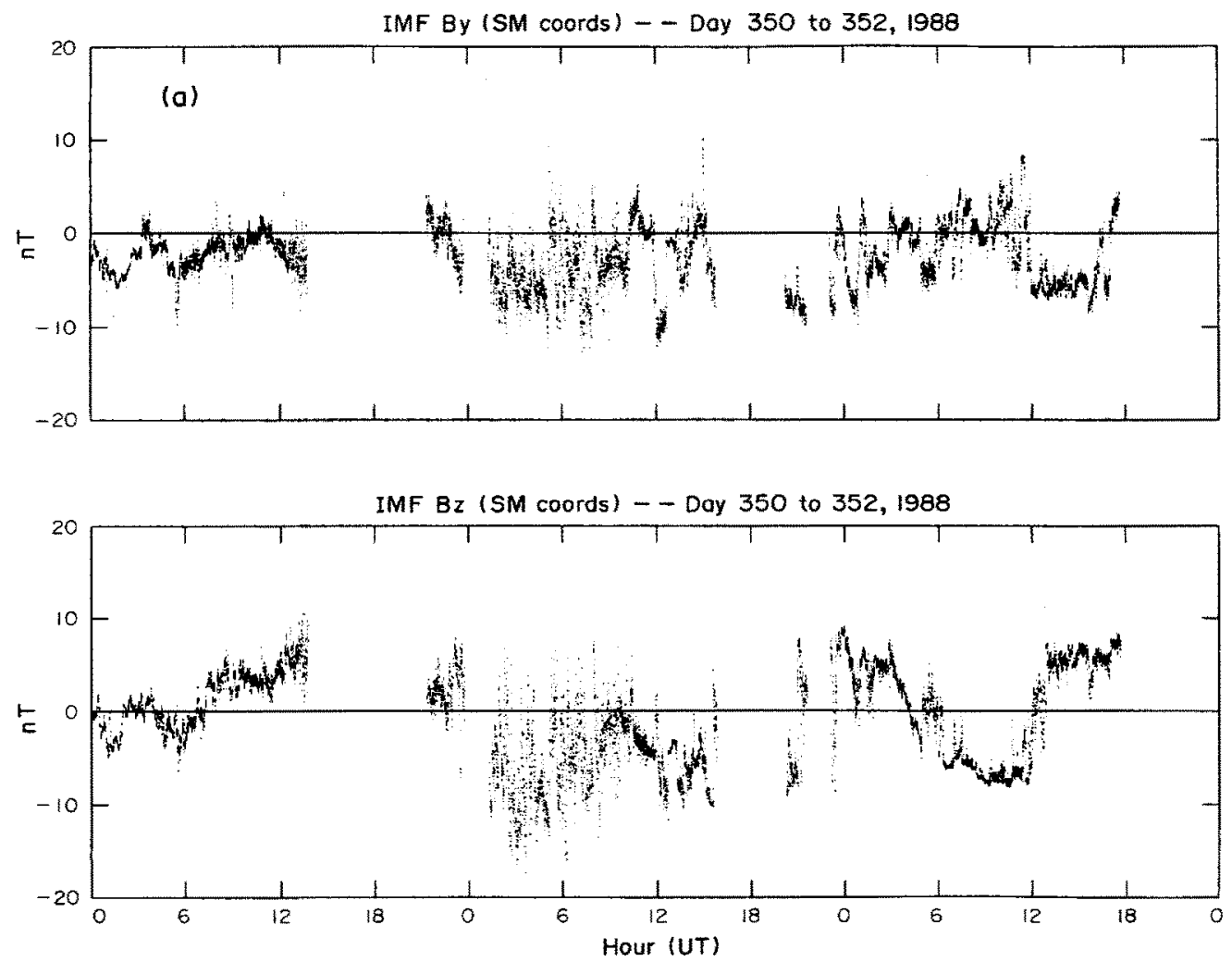

Fig. I (a). 

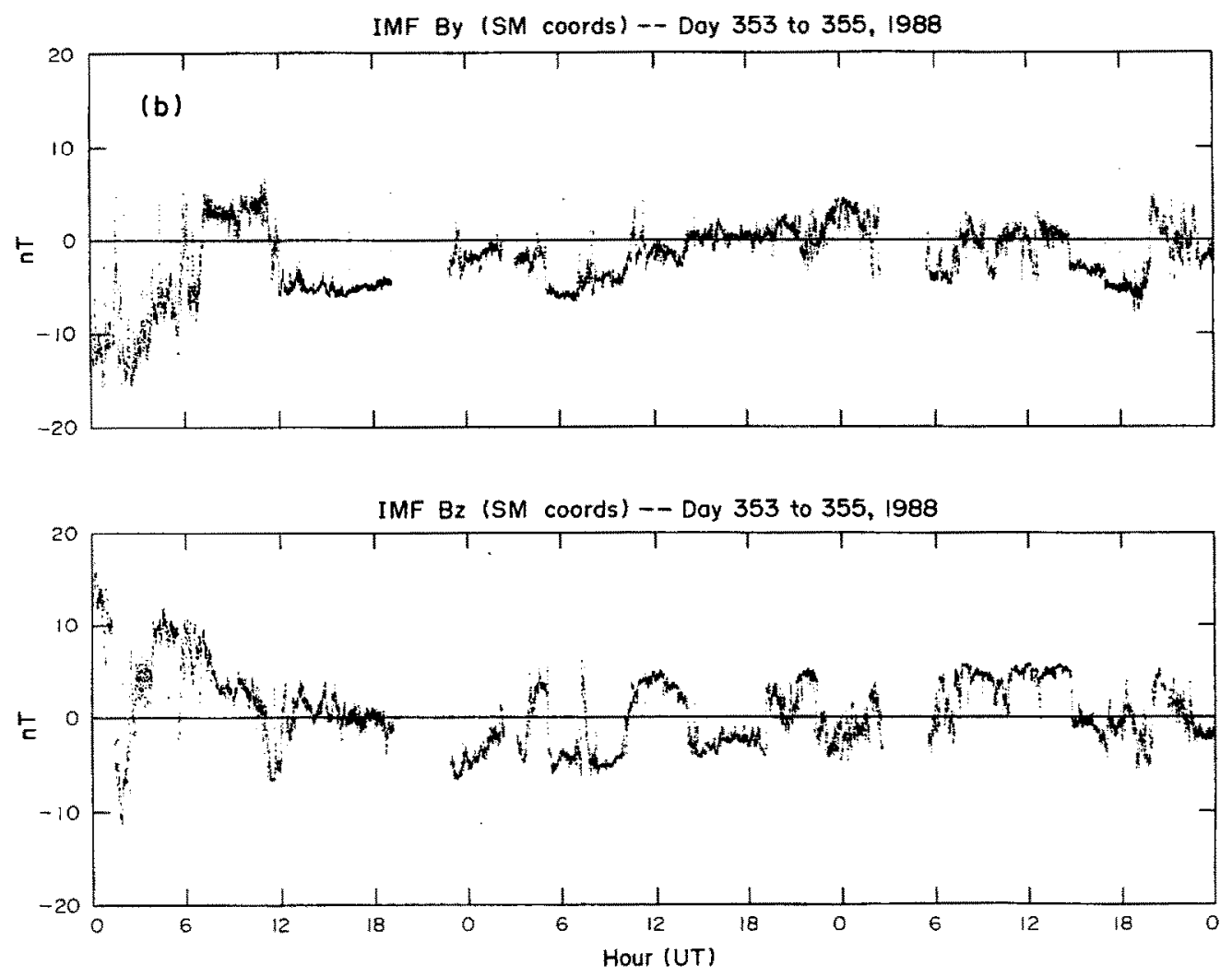

Fig. 1. IMF data acquired by the IMP 8 satellite for (a) days 350-352, 1988, and (b) days 353-355, 1988. Data are shown as a function of Universal Time (UT). The top panel shows the $B$ interplanetary magnetic field component, while the bottom panel shows the $B_{z}$ interplanetary magnetic field component, both displayed in a GSM coordinate system. Periods of long duration northward $\boldsymbol{B}_{z}$ occurrence are day 350 : 07-14 UT; day 352: 12-18 UT; day 353:03-11 UT; day 355:07-15 UT.

18 UT on day 352 , which corresponds to the period when the meridional component halts its equatorward motion, returning once again to the behavior representative of $B_{-}$southward. Case (3) occurs when the horizontal neutral wind is primatily meridional, and once again indicates a marked lessening in the peak magnitude of the flow. Finally, case (4) occurs when the zonal component of the horizontal wind reaches a maximum. Once again, the peak magnitude is suppressed with a greatest value of $200 \mathrm{~m} / \mathrm{s}$.

The behavior of the horizontal neutral wind between 12 and 19 UT on day 353 also deserves mention. As noted above, the IMF $B_{z}$ component was either slightly northward or oscillated back and forth about $0 \mathrm{nT}$. During this period, the horizontal flow would be primarily poleward in direction if the $B$. component were southward. The observed behavior in the neutral wind during this time frame on day 353 matches that observed on day 351 much better than on day 352. A minimum threshold value for effects on the neutral wind by an IMF $B_{z}$ northward component is thus shown very well by this data subset.

Figure 3 displays the meridional and zonal horizontal wind components for Søndre Strømfjord. This site is on the Arctic circle implying that it is not possible to acquire full diurnal coverage even at the winter solstice. The data gaps evident in Fig. 3 are periods when the background Rayleigh scattered sunlight was much brighter than the weak nightglow emission. This station is well within the polar cap during the near magnetic midnight ( $\sim 02 \mathrm{UT})$, but is beneath the auroral oval during dawn and dusk. Consequently, the horizontal neutral wind exhibits a much more complicated behavior at Søndre Strømfjord compared to that described for Thule Air Base. Using cloudless day 351 as the control example for IMF $B_{z}$ southward 
(a)

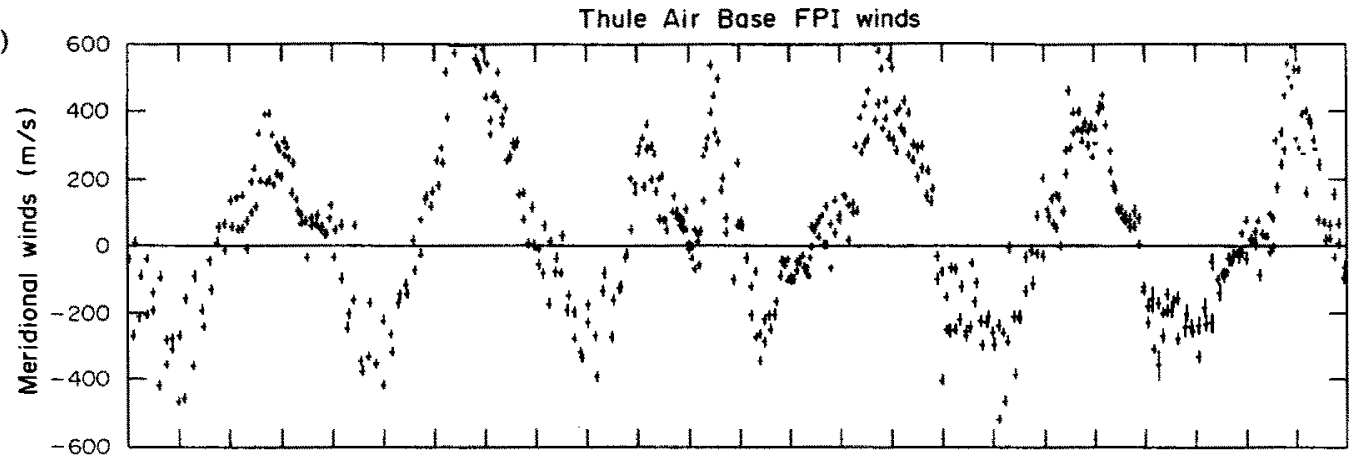

(b)

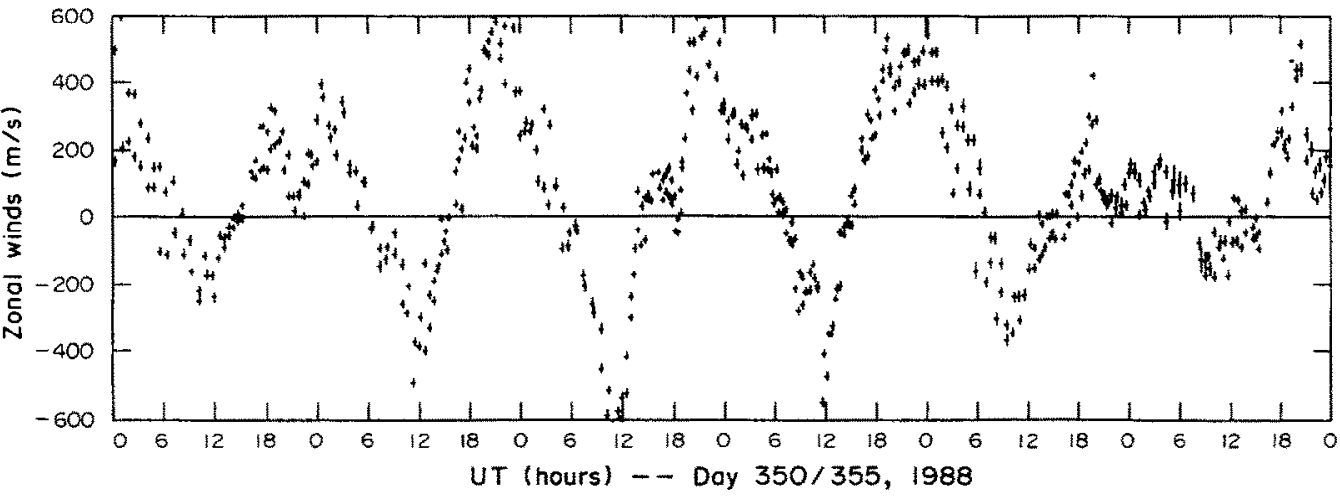

Fig. 2. (a) Meridional and (b) zonal horizontal wind components of the neutral wind in the thermosphere above Thule Air Base between days 350 and 355, 1988. The sign convention for the display has positive meridional wind as northward and positive zonal wind as eastward. Wind values are shown with error bars overlain. Skies above Thule Air Base were clear except for the period day 355: 16-22 UT.

conditions, the meridional wind appears to follow a pronounced diurnal variation pattern, though it appears that daylight obscures the period during which the horizontal neutral flow has its greatest poleward magnitude. The zonal component shows more rapid variations: there is a peak in the zonal flow at both 02 and at 21 UT (11 and 6 p.m. local time, respectively) with a suggestion of a maximum westward flow during the daylight period. This is caused by Søndre Strømfjord moving beneath the return flow of the dawn and dusk circulation cells during those periods.

The individual, long term $B_{z}$ cases described for the Thule Air Base data sets are not as helpful in describing the behavior of the Søndre Strømfjord data. During the periods when $B$ : was northward, Søndre Strømfjord was either in daylight or was under extensive cloud cover. The skies were clear during day 351 , but were overcast during case (3). The period described by case (2) occurred during daylight and the conditions during case (4) were cloudy at the beginning and daylight during the end. Only the first half of case (1) occurred during clear, dark sky conditions. Here, the meridional wind appears to flow northward earlier than on the $B_{z}$ southward control data, but Søndre Strømfjord moves beneath the return dawn sector flow during this interval. It is easier to examine averaged winds at Søndre Strømfjord to detcrmine IMF $B_{z}$ cffects.

\section{Averaged wind components}

In an attempt to quantify the behavior of the horizontal neutral wind at high latitudes, two years of thermospheric wind measurements were collated according to the sign of the IMF $B_{z}$ component. The results during low $K p$ conditions for the meridional component above Thule Air Base are shown in Fig. 4(a) and 4(b) for $B_{z}$ northward and $B$ : southward conditions, respectively. No binning based upon $B_{y}$ was applied in this initial one hour averaging. The 

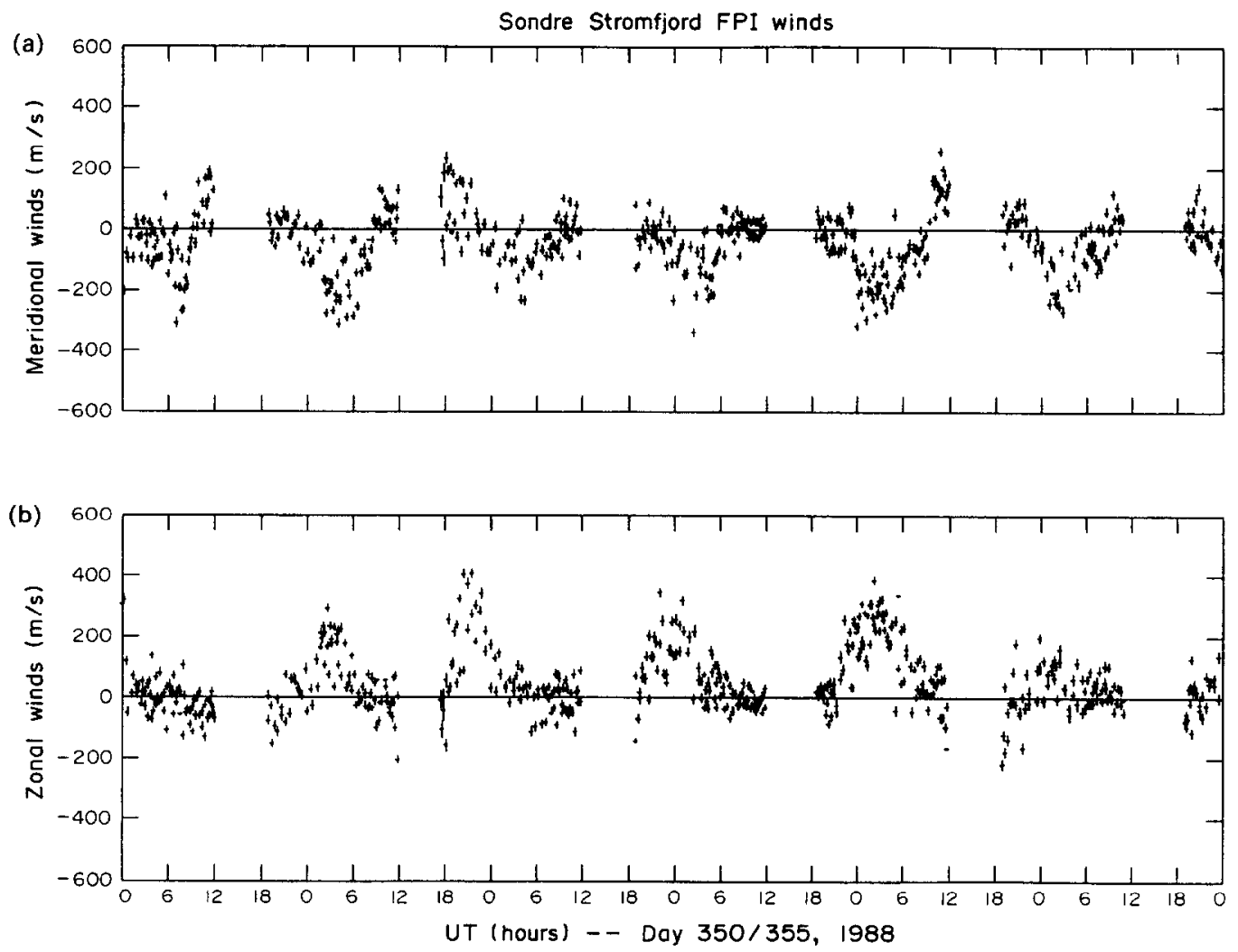

Fig. 3. (a) Meridional and (b) zonal horizontal wind components of the neutral wind in the thermosphere above Søndre Strømfjord, Greenland, between days 350 and 355, 1988. During the data acquisition intervals, the skies were clear except for day 350:00-07 UT; day 352:07-22 UT; and day 353:04-22 UT.

general features described for the December 1988 case study are seen clearly in these figures. The meridional wind experiences its greatest poleward flow at local noon for both $B_{z}$ northward and $B_{z}$ southward, and its greatest equatorward flow at local midnight (04 UT). However, the peak speeds are markedly different for the two directions of $B_{-}$, with the ratio of poleward flows being about $3: 1$ ( $B_{z}$ southward: $B_{z}$ northward) and $2: 1$ for peak equatorward flow. The zonal components both show a strong diurnal variation with the phase about $6 \mathrm{~h}$ offset from the meridional flows. Ratios between $B_{z}$ southward and $B_{z}$ northward are roughly the same as that for the meridional component, about $3: 1$ for maximum eastward flow and about 2:1 for maximum westward flow.

Figure 5 shows similar plots for Søndre Strømfjord. In Fig. 5(a), the maximum poleward flow cannot be shown since it occurs during daylight. However, the maximum equatorward flow, occurring just after local midnight shows a ratio of about $2: 1$ for $B_{z}$ southward: $B_{z}$ northward. The averaged zonal flow dis- plays a less recognizable pattern with speeds measuring either 0 or $100 \mathrm{~m} / \mathrm{s}$ for $B$. southward conditions, and about -50 and $+50 \mathrm{~m} / \mathrm{s}$ for $B$ northward periods.

The two orthogonal components of the horizontal wind are used together to generate the polar dial plots in Fig. 6. Here, the coordinates are shown as geographic latitude (concentric circles with $90^{\circ} \mathrm{N}$ at the center, $60 \mathrm{~N}$ at the largest annulus) and local solar time (the direction to the Sun is from the top of the figure, dawn at the right). The length of the arrow is shown scaled to the $300 \mathrm{~m} / \mathrm{s}$ arrow at the bottom right. The inner circle of arrows corresponds to the averaged neutral wind above Thule Air Base and the outer ring shows the same for Søndre Strømfjord. It is clear that the magnitude of the horizontal neutral wind at high latitudes is markedly decreased if the IMF $B_{z}$ component has a persistent northward component. Also, it is clear that Søndre Strømfjord is beneath the return flow of a twin circulation pattern at both dawn and dusk. Results based upon further subdivision for the 

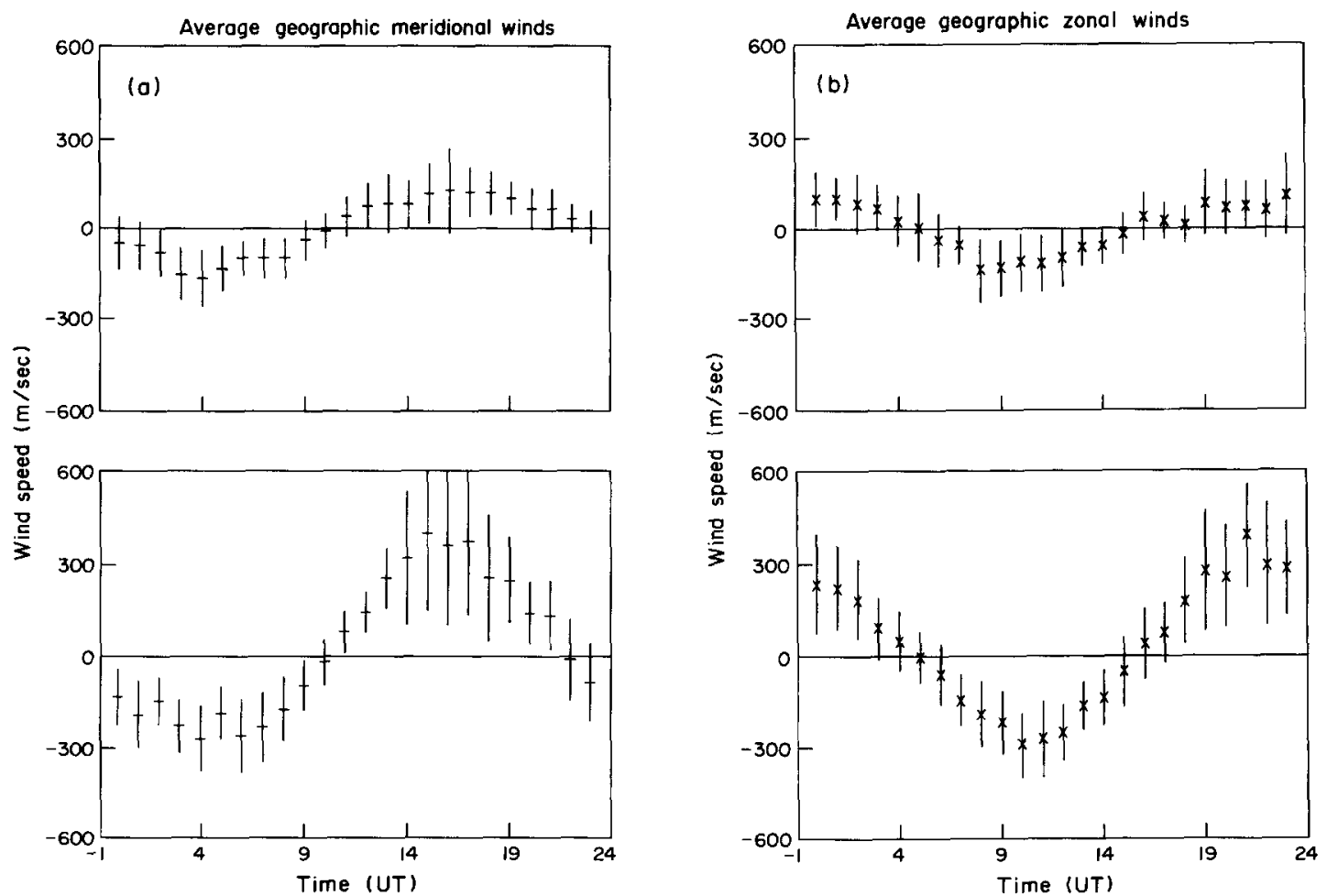

Fig. 4. Averaged (a) meridional and (b) zonal neutral winds at Thule Air Base for IMF $B_{z}$ northward (top)

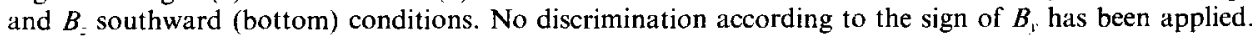
The mean values are shown with $\pm 1 \sigma$ standard deviations overlain and are binned according to the UT hour of observation. The averages apply to data acquired during $K p \leqslant 4$ and clear sky conditions.

$B_{z}$ southward casc according to the sign of $B_{y}$ have been reported by NICIEJEWSKI et al. (1992).

The data for $B_{z}$ northward have been further subdivided according to the absolute magnitude of the IMF $B_{i}$ component. An example of the influence of this component on the high latitude circulation pattern during $B_{z}$ northward conditions at solar maximum periods has previously been reported by MCCORMAC et al. (1991). In their two year study of DE-2 data, they reported a high percentage of sunward winds in the polar cap when the absolute magnitude of $B_{r}$ was smaller than the value of northward $B_{*}$. Figure 7 displays the results for the current two year study. Here, the data that were binned to generate Fig. 6(a) have been subdivided according to the ratio of $\left|B_{v}\right|: B_{z}$. The horizontal wind vectors above Søndre Strømfjord during the midnight sector remain much the same regardless of the binning. Above the dawn and dusk sectors, the horizontal winds show a change in direction, though this shift is probably tied to the sign of the $B_{1}$ component as well (NICIEJEWsKi et al., (1992).

The horizontal winds above Thule Air Base are anti-sunward at all local times when $\left|B_{y}\right|>B_{z}$. The magnitudes are usually between 100 and $150 \mathrm{~m} / \mathrm{s}$ with only a slight deviation from the sunward line. When $\left|B_{y}\right|<B_{z}$, the horizontal winds above Thule Air Base display a confused pattern in the noon sector $(12 \pm 4 \mathrm{~h}$, LST). The magnitudes of the averaged winds are much depressed, roughly one half compared to the case when $\left|B_{y}\right|>B_{z}$. The result of further selection of the data set of Fig. 7(a) based upon the value of $B_{z}$ is shown in Fig. 8. Here, only data corresponding to values of $B_{z}>7 \mathrm{nT}$ have been included in the averages. Also, the data have been transformed to correspond to geomagnetic latitude and magnetic local time to assist in identifying consistent sunward winds as well as to allow one to follow MCCORMAC et al. (1991). From the Thule Air Base data, there is one averaged vector which has a sunward direction, although the data which survive the strict 'selection' make any conclusion rather general. It is clear, though, that anti-sunward winds decrease in magnitude and may eventually become sunward at high latitudes during the conditions described by McCurmac et al. (1991), that is $\left|B_{y}\right|<B_{z}, B_{z}$ greater 

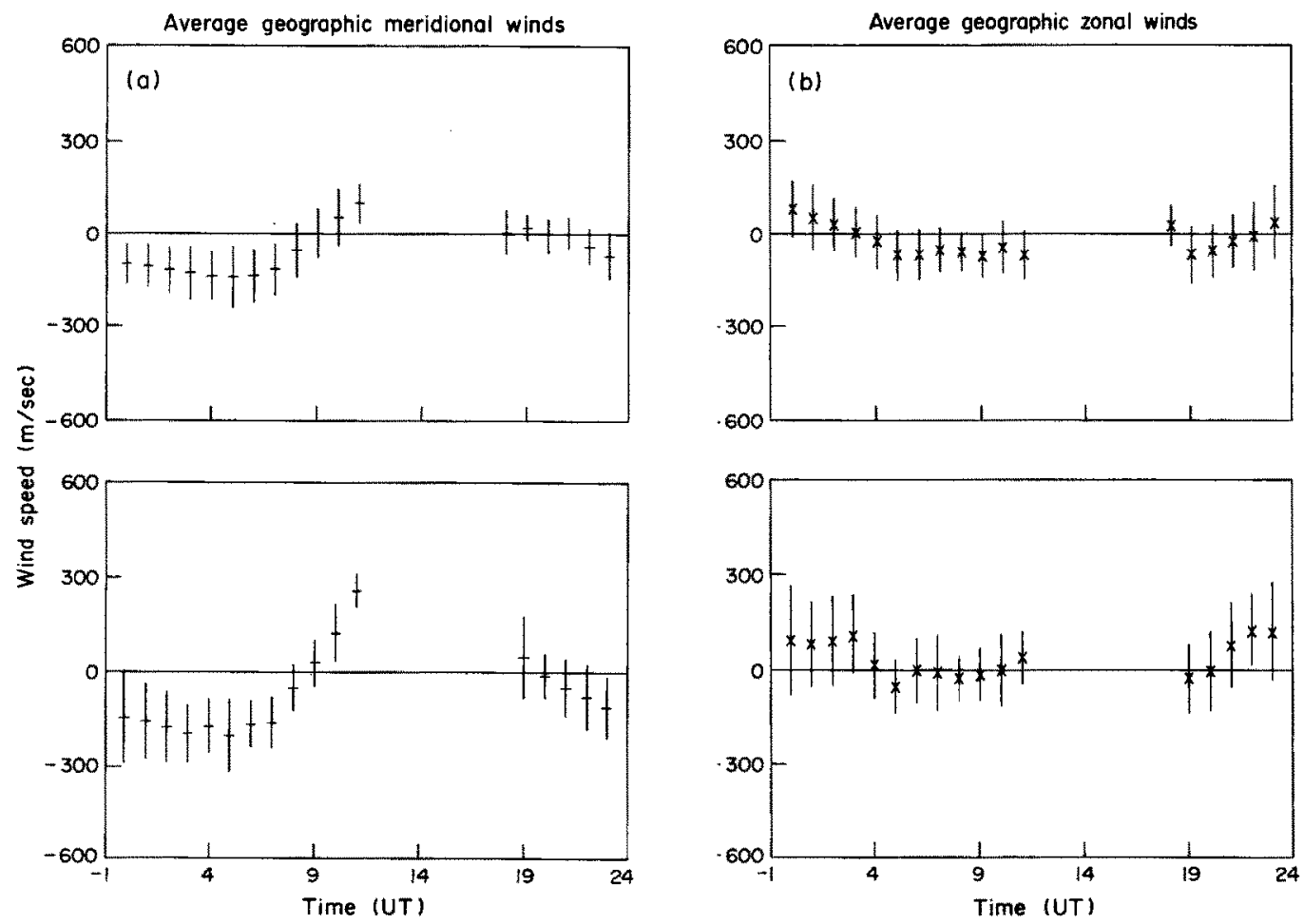

Fig. 5. Averaged (a) meridional and (b) zonal neutral winds at Søndre Strømfjord for IMF $B_{z}$ northward (top) and $B_{z}$ southward (bottom) conditions. The same filtering has been applied as used in Fig. 4.

than a threshold value, and $B_{z}$ northward for several hours.

This study has shown that the magnitude of antisunward neutral flow in the polar cap thermosphere is controlled by the sign of the IMF $B_{z}$ component. A case of flow reversal is illustrated in Fig. 9, which displays results in polar dial form for case (2) described above. In the temporal units used in this plot, the $B_{z}$ component was directed northward between 08 and 14 LST, with no IMF information available for several hours beyond this time limit. In this slightly modified polar dial display (two sets of vectors are shown for both Thule Air Base and Søndre Stromfjord, corresponding to a vector sum of the north and east measurements for each station's inner circle, and a vector sum of the south and west measurements for the outer circles), the horizontal neutral wind displays a sunward component at 14 LST above Thule Air Base. The data displayed correspond to the meridional and zonal components of Fig. 2 for the time period 12 UT, day 352 to 12 UT, day 353 , and more clearly highlight the observed sunward flow.

The response of the thermospheric neutral wind at high latitudes may be represented quite well by a low pass filter with a time constant of several hours. Momentum transfer from convecting plasma provides a time varying impulse to the neutral circulation and, if the plasma maintains a flow representative of $B_{z}$ northward conditions for a few hours, then the neutral winds will follow. The plasma drifts at high latitudes for the period described in Fig. 9 have been measured by a digisonde (THAYER et al., 1990) and are the subject of a future publication. They show that the ion drifts were sunward during the period when the neutral wind flow was sunward. Sunward winds at high latitudes in the northern hemisphere were also reported by SмIтH et al. (1989) for another period of persistent $B_{z}$ northward.

\section{CONCLUSIONS}

This study provides the following conclusions.

(1) The neutral wind field at high latitudes in the northern hemisphere is influenced by the IMF $B_{\text {: }}$ component. If the $B_{z}$ component remains northward for several hours, then the average peak poleward horizontal neutral wind speed will be roughly one-third of 
Thule and Sondre Stromfjord FPI $\mathrm{Kp} \leqq 4, B z N$

(a)

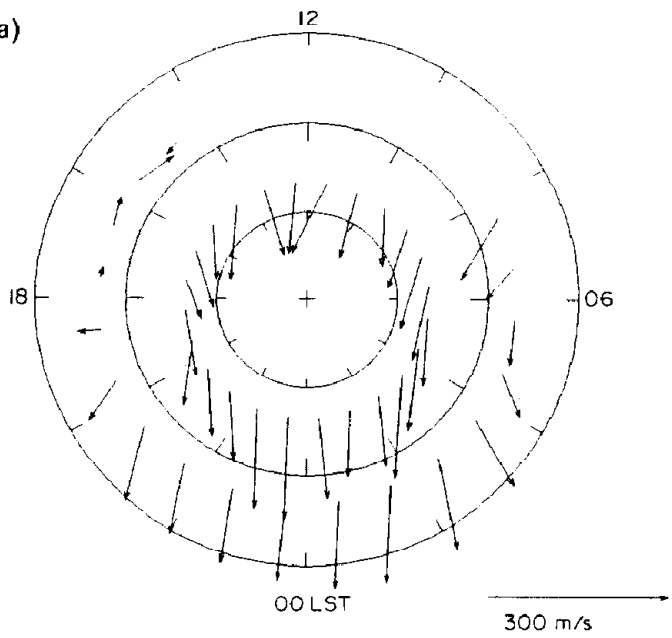

Thule and Sondre Stromfjord FPI $\mathrm{Kp} \leqq 4, B z \mathrm{~S}$

(b)

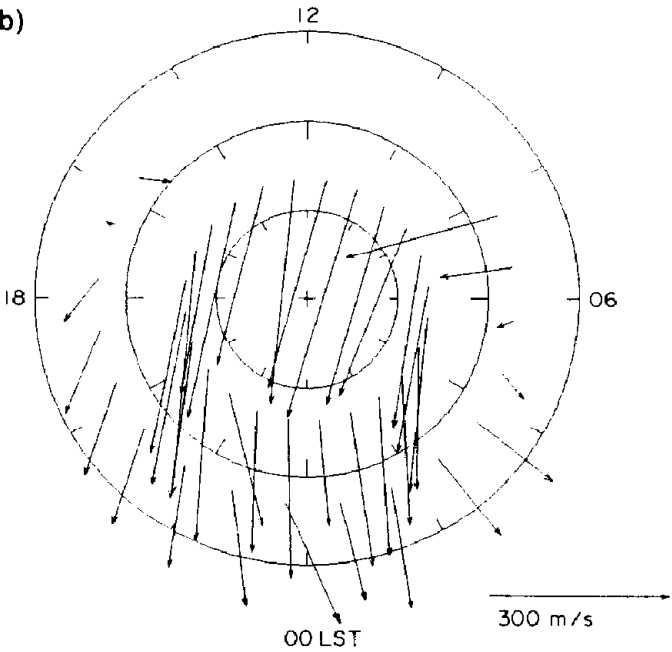

Fig. 6. Polar dial plots for (a) $B_{z}$ northward and (b) $B$ southward conditions of the horizontal neutral wind flow at high latitudes when $K p \leqslant 4$. The grid corresponds to geographic latitude $\left(90^{\circ} \mathrm{N}\right.$ at the center, $60^{\circ} \mathrm{N}$ at the outside), and local solar time (sunward at the top, dawn at the left). The wind speed is scaled to the length of the control arrow at the bottom right. The tails of the inner circle of arrows are located at Thule Air Base, while the tails of the incomplete outer circle of arrows correspond to Søndre Strømfjord.

the value for $B_{z}$ southward or $B_{z} \sim 0 \mathrm{nT}$ conditions. The average peak equatorward speed will be approximately onc-half for the same situation.
Thule and Sondre Stromfjord FPI $\mathrm{Kp} \leqq 4, \mathrm{Bz} N$, abs (By) it Bz

(a)

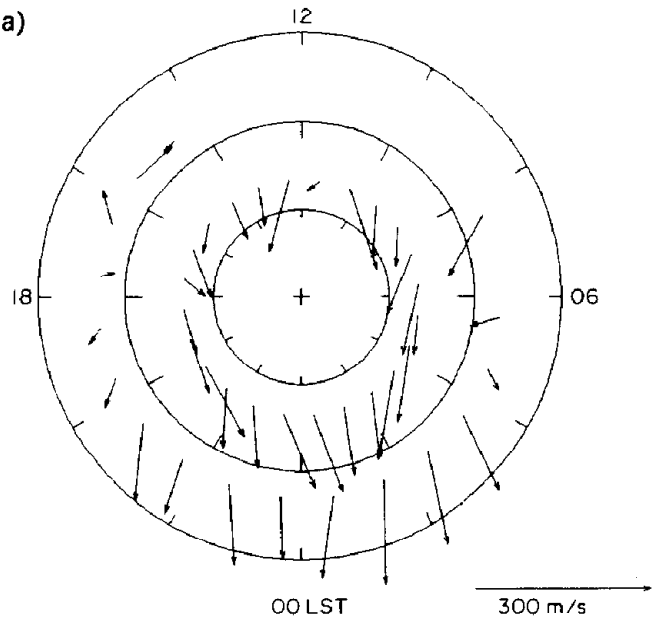

Thule and Sondre Stromfjord FPI

$K p \leqq 4, B z N$, abs (By) gt $B z$

(b)

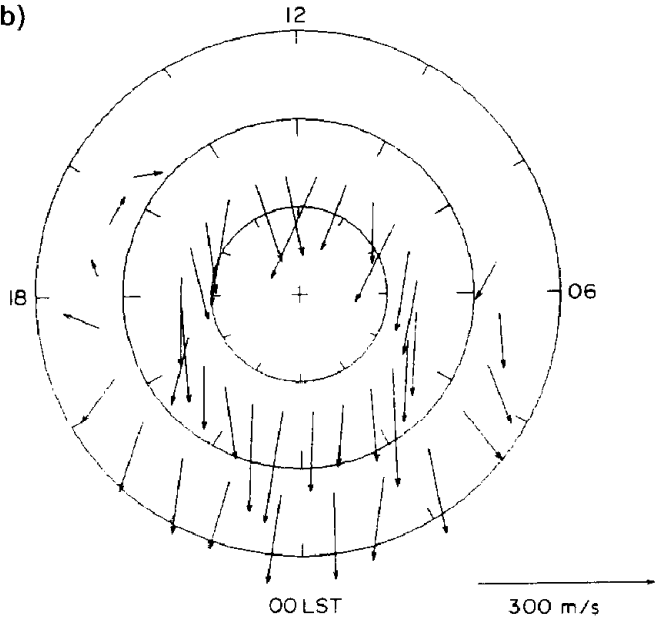

Fig. 7. Polar dial plots for $B_{z}$ northward conditions, $K p \leqslant 4$, and (a) $\left|B_{y}\right|<B_{z}$, (b) $\left|B_{y}\right|>B_{z}$. The grid is the same as shown in Fig. 6.

(2) In addition, if $\left|B_{y}\right|<B_{z}$, then the average peak poleward horizontal neutral wind speed will be approximately halved once again.

(3) In addition, if $\left|B_{y}\right|<B_{z}$, and $B_{z}$ is greater than $\sim 7 \mathrm{nT}$, then sunward winds can develop at the highest latitudes during persistent $B_{z}$ northward. These occurrences are quite rare, but cases have been observed.

These results point to the possibility of predicting 


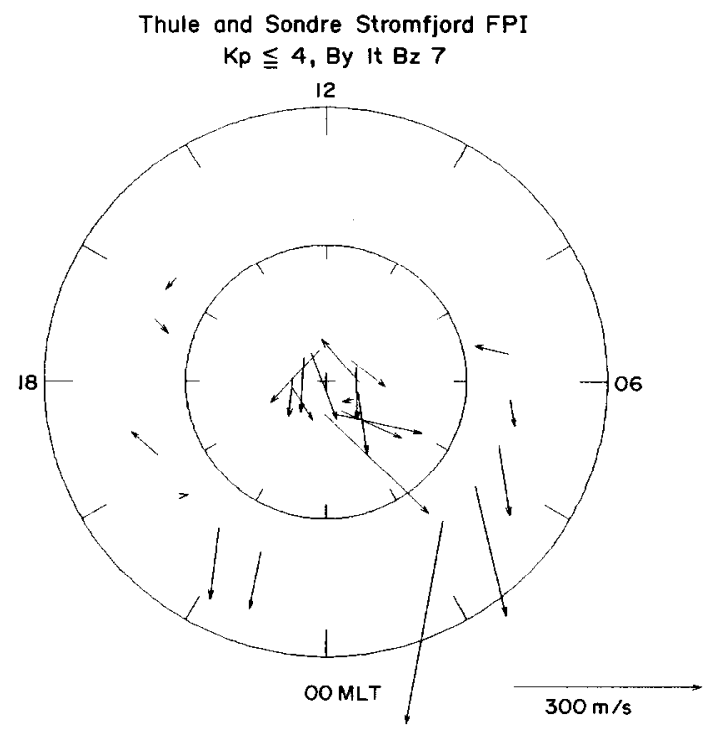

Fig. 8. Polar dial plot for $\left|B_{y}\right|<B_{z}$, and $B_{z}>7 \mathrm{nT}$. Here, the grid has been modified to display geomagnetic latitude $(90 \mathrm{~N}$ at the center, and $70^{\circ} \mathrm{N}$ at the perimeter) and magnetic local time.

the sign of the $B_{z}$ component based solely on the horizontal neutral wind in the thermosphere at high latitudes. This information would be valuable in providing IMF information during periods in which there are no satellites within the solar wind providing measurements of the interplanetary magnetic field.

Acknowledgements-The IMF data were kindly provided by C. Valladares, with interpretation algorithms shared by $\mathbf{B}$. Claucr. Discussions with J. Thayer and G. Crowley were much appreciated. The authors acknowledge J. Meriwether Jr for his substantial efforts at maintaining the two optical

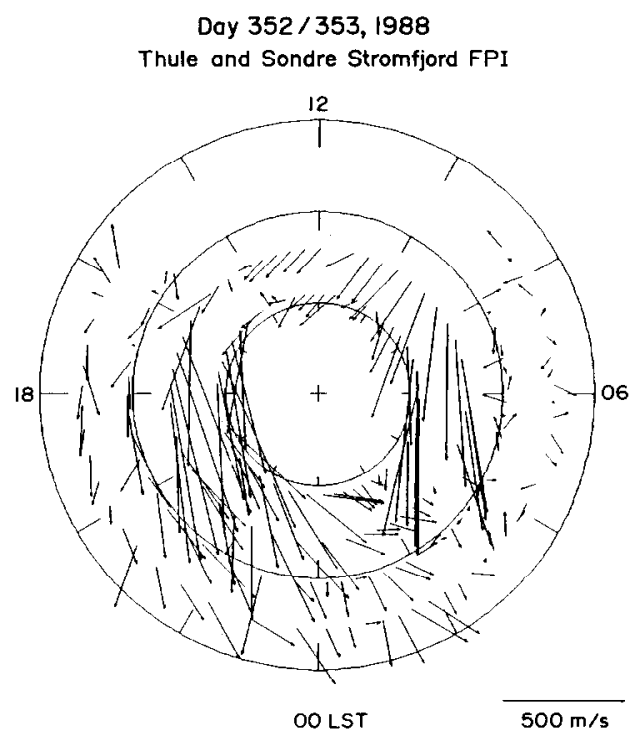

Fig. 9. Polar dial plot in geographic latitude, local solar time coordinates for the period 08 LST, day 352, to 08 LST, day 353. The length of each vector is scaled to the length of the $500 \mathrm{~m} / \mathrm{s}$ vector at bottom right. Note that each station has two sets of vectors associated with it, with their tails describing inner and outer circles. These vectors were produced by combining the north and east directed measurements for each station's inner circle, and the south and west directed measurements for each station's outer circle. The tails of the vectors were plotted at the intersection point for $250 \mathrm{~km}$ altitude that corresponded to the combined vector's direction.

facilities in their early years. This work was sponsored by National Science Foundation grants ATM8822530, ATM90-02608, and ATM9101865, and by the Air Force under grant F19628-89-K-0047.
Heelis R. A., Reiff P. H., Winningham J. D. and HANSON W. B.

HEPPNER J. P.

HeppNer J. P. and Maynard N. C.

Hernandez G., McCormac F. G. and SMITH R. W.

KILLEEN T. L. and HaYS P. B.

Killeen T. L., Hays P. B., Spfncfir N. W. and WHARTON L. E.

Killeen T. L., Heelis R. A., Hays P. B., SPENCER N. W. and HANSON W. B.

\section{REFERENCES}

1986 Ionospheric convection signatures observed by DE2 during northward interplanetary magnetic field. $J$. geophys. Res. 91, 5817.

1977 Empirical models of high-latitude electric fields. $J$. geophys. Res. 82, 1115 .

1987 Empirical high-latitude electric field models. J.geophys. Res. 92, 4467.

1991 Austral thermospheric wind circulation and interplanetary magnetic field orientation. J.geophys. Res. 96, 5777 .

1984 Doppler line profile analysis for a multichannel FabryPerot interferometer. Appl. Optics 23, 6I2.

1982 Neutral winds in the polar thermosphere as measured from Dynamics Explorer. Geophys. Res. Lett. 9,957.

1985 Neutral motions in the polar thermosphere for northward interplanetary magnetic field. Geophys. Res. Lett. 12, 159. 
KoHL H. and KING J. W.

McCormac F. G., Killeen T. L., Gombosi E., HAYS P. B. and SPENCER N. W.

McCormac F. G., Killeen T. L. and Thayer J. P.

McCormac F. G. and Smith R. W.

Meriwether J. W. JR and ShlH P.

Meriwether J. W. JR, Tepley C. A., Price S. A., HAYS P. B. and COGGER L. L.

Niciejewski R. J., Killeen T. L., Johnson R. M. and ThaYer $\mathbf{J}$. P.

Ponthieu J.-J., Killeen T. L., Lee K.-M. Carignan G. R., Hoegy W. R. and Brace L. H.

Rees D., Fuller-Rowel T. J., Gordon R., Smith M. F., Maynard N. C., Heppner J. P., Spencer N. W., Wharton L., Hays P. B. and KILLEEN T. L.

Sica R. J., Hernandez G., Emery B. A., Roble R. G., Smith R. W. and Rees M. H.

Smith R. W., Meriwether J. W. JR, Hernandez G., Rees D., Wickwar V., de la Beaujardière $O$. and KilleEN T. L.

Thayer J. P., Killeen T. L., McCormac F. G., Tschan C. R., Ponthieu J.-J. and SPENCER N. W.

Thayer J. P., Niciejewski R. J., Killeen T. L., Buciatu J., Reinisci B. W. and Crowley G.
1967 Atmospheric winds between 100 and $700 \mathrm{~km}$ and their effects on the ionosphere. J. atmos. torr. Phys. 29, 1045.

1985 Configuration of the high-latitude thermospheric neutral circulation for IMF $B_{r}$ negative and positive. Geophys. Res. Lett. 12, 155.

1991 The influence of IMF $B_{r}$ on the high-latitude thermospheric circulation during northward IMF. J geophys. Res. 96, 115.

1984 The influence of the interplanetary magnetic field $Y$ component on ion and neutral motions in the polar thermosphere. Geophys. Res. Lett. 11, 935.

1987 On the nighttime signatures of thermospheric winds observed at Sondrestrom, Greenland, as correlated with interplanetary magnetic field parameters. $A n n$. Geophys. 5A, 329.

1983 Remote ground-based observations of terrestrial airglow emissions and thermospheric dynamics at Calgary, Alberta, Canada. Opt. Engng 22, 128.

1992 The behavior of the high-latitude $F$-region neutral thermosphere in relation to IMF parameters. Adv. Space Res. 12(6), 215.

1988 Ionosphere-thermosphere momentum coupling at solar maximum and solar minimum from DE-2 and AE-C data. Phys. Scripta 37, 447.

1986 A theoretical and empirical study of the response of the high latitude thermosphere to the sense of the ' $Y$ ' component of the interplanetary magnetic field. Planet. Space Sici. 34, 1 .

1989 The control of auroral zone dynamics and thermodynamics by the interplanetary magnetic field dawndusk (Y) component. J. geophys. Res. 94, 11,921 .

1989 Mapping the wind in the polar thermosphere: a case study within the CEDAR program. EOS Trans. 70, 168 .

1987 Thermospheric neutral wind signatures dependent on the east-west component of the interplanetary magnetic field for northern and southern hemispheres as measured from Dynamics Explorer-2. Ann. Geophys. 5A, 363.

1990 Ground-based observations of ion/neutral coupling at Thule and Qânâq, Greenland: IMF $B_{z}$ dependence. EOS Trans. 71, 581. 